\title{
Considerations on the Breeding and Weaning of Buffalo Calf
}

\author{
Luigi Zicarelli*
}

\author{
Department of Veterinary Medicine and Animal Production, Università di Napoli Federico II, Italy
}

\begin{abstract}
The buffalo calf is more challenging to adapt to the transition from breast milk to other substitutes that favor weaning.

Growth in the pre-weaning period is affected by the amount of reconstituted milk consumed. When the quantity of reconstituted milk consumed is low, the weaning weight is also low. The gap between the latter and the optimal weight will never be eliminated because the species cannot perform compensatory growth, such as cattle. There is a delay in reaching an optimal live weight to start puberty. The age at first birth is, in fact, lower in those countries that leave all the milk to the calf for meat production or as happens in Italy where there is a suitable milk substitute.

In Italy, it has been verified that calves taking almost ad libitum quantities of cow's milk weigh more than $140 \mathrm{~kg}$ at 4 months and have their first birth at the age of 22-26 months. As adults, they have an almost zero percentage of vaginal or uterine prolapse.

In further experiences on 3672 heifers, it was possible to verify "ex-post" that the calves that had taken a more significant quantity (150 kg vs. 105) of milk substitute had shown age at the first birth in advance of about 6 months (28, 5 versus 34).

Future investigations should verify the effect of weaning birth and not just the cost of weaning. Age at first birth is not only an economic parameter, but it is useful for an early evaluation of bulls in progeny tests.
\end{abstract}

Keywords: Buffalo calf, calf breeding, weaning, milk replacer.

\section{INTRODUCTION}

Interest in raising and weaning calves has increased with the demand for buffalo milk. In countries where the species is intended for meat production or work, the calf receives breast milk until weaning beyond 9 months [1].

On the contrary, in countries where milk production is the main objective, breeders have tried to reduce the weaning age and to use reconstituted milk with the lowest possible cost; these measures are intended to anticipate the availability of milk for sale. The characteristics of the reconstituted milk, with the exception [2] of some differences (copper less than 5 $\mathrm{mg} / \mathrm{kg}$ ), are superimposable to those used for bovine calves.

The tendency to wean buffalo calves as early as possible depends on the fact that buffalo milk has always been paid from 2 times (in countries where it is used as drinking milk) to 3-4 times (in Italy where it is used for the production of a special cheese) more than cow's milk.

In Italy, until a few decades ago, buffalo calves could suck with three, two, and one-quarter of the udder for the 1st, 2nd, and 3rd months of life, and they

*Address correspondence to this author at the Department of Veterinary Medicine and Animal Production, Università di Napoli Federico II, Italy; Tel: 3346939579; E-mail: zicarell@unina.it were subsequently kept alive only to maintain milk production. To make sure the females did not stop producing milk when their calf died, the skin of the dead son was placed on top of another calf to deceive the mother with its familiar smell. At the end of breastfeeding, the calves were left to pasture, and they received the food that the breastfeeding females left behind. With this technique, if pasteurellosis did not occur, survival was relatively high; however, 8-months subjects weighed less than $100 \mathrm{~kg}$, and $400 \mathrm{~kg}$ of live weight was reached at the age of over 34 months.

\section{STUDIES CARRIED OUT IN}

1964 Ferrara et al. [3] showed that it was possible to wean buffalo calves using cow's milk. And to obtain optimal growth (approximately $1 \mathrm{~kg} / \mathrm{day}$ ), it was necessary to administer 7.12 and $10.44 \mathrm{~kg} /$ day of buffalo milk and cow milk respectively up to the fourth month of age. Today there are still some farms where after the colostral phase (between 3 and 7 days), weaning is carried out by suckler cows, which give milk, according to their production, to 2-4 calves that suck directly from the cows twice per day.

Recently (personal communication), in some farms, some cows are milked to supply milk to the buffalo calves almost ad libitum for a maximum of 4 months when the subjects weigh more than $140 \mathrm{~kg}$. These subjects give birth for the first time at the age of 22-26 months and have an almost zero percentage of vaginal or uterine prolapse. 
In a previous contribution [4], it was reported that vaginal and uterine prolapse increased in buffalo herds in the late 1970s. This period coincided with the growing demand for buffalo milk and the everincreasing use of reconstituted milk.

Buffalo calves' actual nutritional needs were not taken into account in formulating the various reconstituted kinds of milk. Artificial feeding with "less unsuitable" milk substitutes has intensified neonatal gastrointestinal diseases, which have also negatively influenced the absorption of minerals. In our opinion, this factor represents a not negligible cause of the prolapse that occurs in adulthood. In countries where calves still take breast milk, vaginal prolapse is rare. Examining Mediterranean buffalos (Egypt and Latin America) or any other breed or crossbreeds in other countries in the past, what is striking is the remarkable diversity of the conformation of the basin. In the past, unlike the buffaloes bred in Italy, there were no sloping croups; and the relationships between the three widths (front, central, and rear) of the basin were more proportionate, although the growth of the buffaloes in these countries was slower.

The correct pelvic belt architecture, and therefore a harmonic pelvis, is probably influenced by the minerals absorbable in the early stages of life. In formulating milk substitutes for buffalo calves, producers do not take into due account that buffalo milk has a higher $\mathrm{Ca}$ / $\mathrm{P}$ ratio ( $\mathrm{Ca} 1.8-2 \mathrm{~g} / \mathrm{kg}, \mathrm{P}$ approximately $1.1 \mathrm{~g} / \mathrm{kg}$, ratio equal to 1.73 ) of that vaccine milk (Ca $1.1 \mathrm{~g} / \mathrm{kg}, P$ $0.8 \mathrm{~g} / \mathrm{kg}$, ratio equal to 1.33 ) and that the intake capacity of a buffalo calf is less than that of the bovine calf ( $2 \%$ vs. $2.4 \%-2.8 \%$ DM / $100 \mathrm{~kg}$ of live weight).

In buffalo milk, in addition to a different $\mathrm{Ca} / \mathrm{P}$ ratio, there is a narrower $\mathrm{Ca} /$ protein ratio (respectively 0.35 and 0.42 in cattle and buffaloes), which leads to hypothesize a $\mathrm{Ca}$ function not targeted only at coagulation process but to other physiological needs. According to Ferrara and Intrieri [5], the percentage of colloidal calcium in buffalo milk is about $80 \%(1,625 \mathrm{~g}$ of colloidal calcium $/ \mathrm{kg} / 2.029 \mathrm{~g}$ of total calcium $/ \mathrm{kg}$ ) while in cattle milk it is about $67 \%$ (11). The percentage of colloidal $P$ is also about $66 \%$ [6] and about $45 \%$ [5] in buffalo and cow's milk, respectively. The greater presence of $\mathrm{Ca}$ and $\mathrm{P}$ colloidal testifies to particular nutritional needs in the buffalo calf compared to the bovine calf as the buffalo calf has a more developed skeletal system which, by reducing its specific weight, allows it to swim more easily (buffalo river).
The buffalo calf's lower intake capacity ( $2 \%$ vs. $2.4 \%$ of the live weight for the buffalo and the bovine respectively) in the first months of life leads to lower ingestion of DM for the buffalo by $16.67 \%$ [7]. If a buffalo calf is fed cow's milk and ingests a smaller amount of dry matter, it will take on a diet characterized by a lower content, except lactose, of all nutrients (Table 1).

It is known that milk reconstituted under the most favorable conditions is formulated with $60 \%$ of cow's milk proteins and for the rest with whey and vegetable proteins. It follows that the percentage of colloidal $\mathrm{Ca}$ and $P$ is even lower. There are no substantial differences in weight between the two species, but in buffalo calves, the skeletal system affects the live weight in a higher percentage. It is conceivable that the greater presence of $\mathrm{Ca}$ in buffalo milk and its better absorbability thanks to the colloidal shape are aimed at the formation of the skeleton, as well as guaranteeing an adequate $\mathrm{Ca} /$ casein ratio useful for promoting coagulation in the abomasum. These observations suggest that to meet the needs of $\mathrm{Ca}$ and $\mathrm{P}$ during the period of formation of the basin; the buffalo calf must take an adequate amount of reconstituted milk, the content of which is low in colloidal $\mathrm{Ca}$ and $\mathrm{P}$. An alternative is represented by the cow's milk in which the presence of these elements in the colloidal form is certain even if it remains lower than the needs. This claim is justified by the field observation that farms that use adequate quantities of cow's milk produce heifers whose age at first birth is $22-26$ months and have little or no incidence of vaginal or uterine prolapse.

It should be emphasized that vaginal and uterine prolapse often compromises production and subsequent reproductive career.

\section{RECENT STUDIES}

Among the various contributions relating to tests carried out on the weaning of the buffalo calf, we mention two carried out in Italy. Table 2 summarizes the main results of the two contributions.

At the $X$ National Congress of the Scientific Association of Animal Production (ASPA), Palladino et al. [6] showed that the lower administration of acidified reconstituted milk does not change the total daily intake of dry matter between 10 and 80 days of life (Figure 1) among the subjects who had taken a major (group A) and a minor (group B) quantity of reconstituted milk, but it causes a lower daily weight gain (Figure 2 ) in the 
Table 1: Chemical Composition of Buffalo and Bovine Milk as Fed and on Dry Matter (DM) and Quantity of Nutrients Equivalent to $83,33 \%(2 / 2,4)$ of DM

\begin{tabular}{|c|c|c|c|c|c|c|c|c|}
\hline & \multicolumn{2}{|c|}{$\%$ as fed } & \multicolumn{2}{|c|}{$\% \mathrm{DM}$} & \multicolumn{2}{|c|}{$83,33 \%$ DM milk of } & \multirow[b]{2}{*}{$\% \mathrm{~d} / \mathrm{c}$} & \multirow[b]{2}{*}{$\Delta$} \\
\hline & a & b & c & d & e & f & & \\
\hline & cattle & buffalo & cattle & buffalo & cattle & buffalo & $\begin{array}{c}\% \text { DM Buffalo/\% } \\
\text { DM cattle }\end{array}$ & $\% d / e-100$ \\
\hline Ash \% & 0.70 & 0.83 & 5.38 & 4.55 & 4.48 & 3.79 & 84.57 & -1.53846 \\
\hline Fat $\%$ & 4.00 & 8.00 & 30.77 & 43.88 & 25.64 & 36.57 & 142.61 & -41.5679 \\
\hline Lactose $\%$ & 4.90 & 4.80 & 37.69 & 26.33 & 31.41 & 21.94 & 124.91 & 19.29358 \\
\hline dry matter $\%$ & 12.70 & 18.23 & 100 & 100 & 83.33 & 83.33 & 100 & -16.67 \\
\hline Kcal & 737 & 1185 & 5671 & 6498 & 4726 & 5415 & 114.58 & -27.2699 \\
\hline MFU & 21 & 32 & 1.60 & 1.77 & 1.33 & 1.47 & 110.62 & -24.8588 \\
\hline$\%$ Colloidal P & 45 & 66 & & & & & & \\
\hline Colloidal $\mathrm{Ca}$ & 0.804 & 1.6 & 6.33 & 8.78 & 5.27 & 7.32 & 138.70 & -39.98 \\
\hline Colloidal P & 0.315 & 0.726 & 2.48 & 3.98 & 2.07 & 3.32 & 160.48 & -47.99 \\
\hline
\end{tabular}

Table 2: Main Results of the Contributions of Palladino et al. and Vecchio et al.

\begin{tabular}{|c|c|c|c|c|}
\hline \multirow{3}{*}{ group } & \multicolumn{2}{|c|}{ Vecchio et al. (2013) } & \multicolumn{2}{|c|}{ Palladino et al. (1993) } \\
\hline & $6-90 \mathrm{gg}$ & $6-90 \mathrm{gg}$ & $10-80 \mathrm{gg}$ & $10-80 \mathrm{gg}$ \\
\hline & gr/die & gr/die & gr/die & gr/die \\
\hline Reconstituted milk (RM) up to 80 days $(\mathrm{kg})$ & & & 60.8 & 50.6 \\
\hline Reconstituted milk (RM) - gr / day between 6 and 90 days & 1000 & 1000 & & \\
\hline Concentrated feed + hay up to 80 days $(\mathrm{kg})$ & & & 585 & 699 \\
\hline Concentrated feed + hay up to 90 days $(\mathrm{kg})$ & 732 & 877 & & \\
\hline Total DM ingested (gr / day) up to 80 days & & & 1285 & 1281 \\
\hline$\% \mathrm{RM} / \mathrm{DM}$ up to 90 days & 57.73 & 53.27 & & \\
\hline Daily growth up to 80 days & & & 726 & 607 \\
\hline Daily growth up to 90 days & 633 & 677 & & \\
\hline Live weight at 80 days & 96.6 & 98.0 & 93.2 & 84.9 \\
\hline Average live weight at $10-80$ days & & & 67.75 & 63.6 \\
\hline$\%$ DM / kg LW at $10-80$ days ** & & & 1.65 & 1.75 \\
\hline Live weight at 90 days & 101.9 & 104.3 & $97.16^{*}$ & $89.46^{*}$ \\
\hline Average weight $6-90$ days & 73.32 & 73.65 & & \\
\hline
\end{tabular}

* estimate; ${ }^{* *} \mathrm{DM}=$ dry matter; $\mathrm{LW}=$ live weight. 


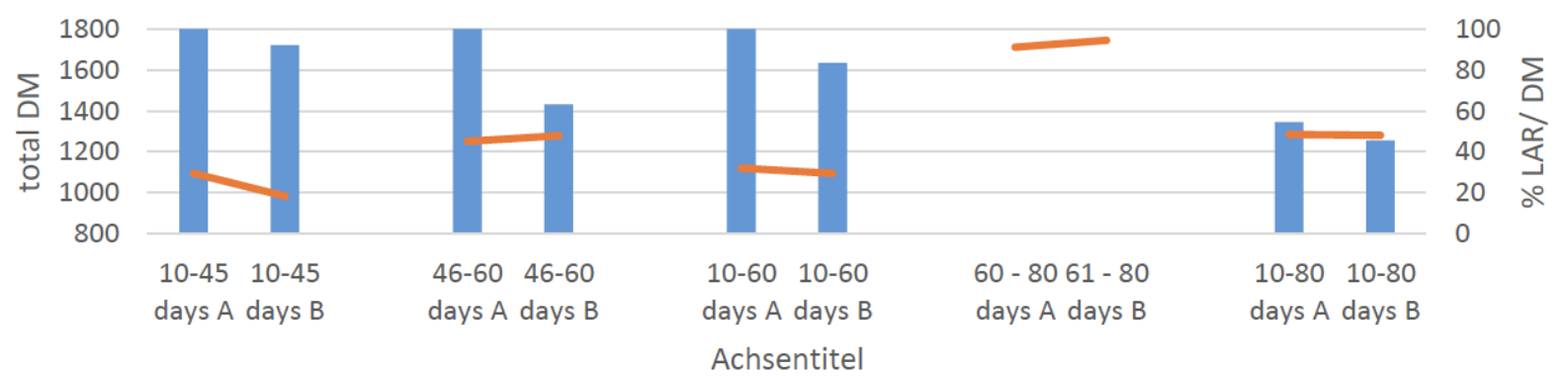

$\%$ LAR/DM total DM gr

Figure 1: Daily ingestion (\%) of LAR (\% LAR/DM) and total ingestion of dry matter (DM gr) in groups $A$ and $B$.



$\%$ LAR/DM DWG gr

Figure 2: Daily weight gain (DWG gr) and percentage of reconstituted milk acidified (LAR) / dry matter (DM) in groups A and B.

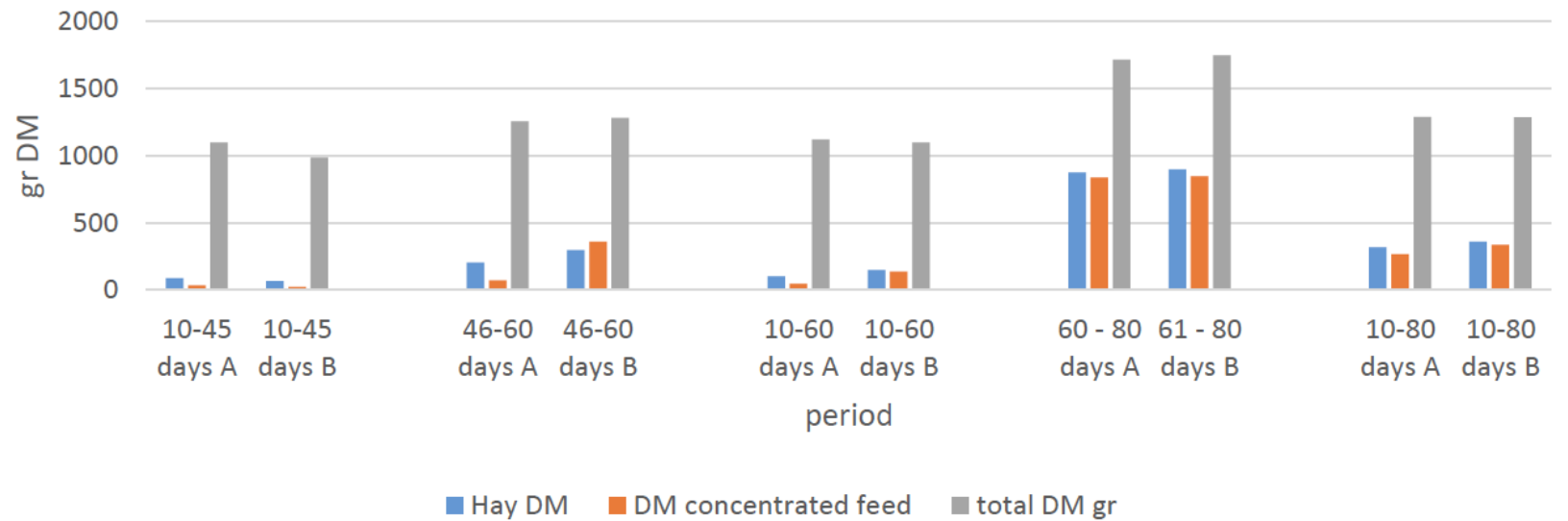

Figure 3: Ingestion of total dry matter, hay and concentrated feed in groups A and B.

subjects of group B. This finding shows that, unlike what has been observed in the bovine calf, the buffalo calf does not increase the consumption of concentrate or hay when the administration of the dry substance of the reconstituted milk decreases (Figure 3 ).

The buffalo calf completes the eruption of the incisors later than the bovine one (about 25 days against 8 days), and this shows that it is less early. This delay is accompanied by a higher sensitivity of the buccal mucosa. Therefore it is necessary to use a softer rubber for the suction cups than the one used for the bovine calves. The sensitivity of the mucosa is a not negligible cause of the delay in the intake of the dry substance which is different from milk or its substitutes e this makes weaning more difficult.

Vecchio et al., [7] have shown that it is possible to administer reconstituted milk once a day by doubling the concentration of reconstituted milk between 9 and 60 days of life from 18 (group G1) to $36 \%$ (group G2) and between 61 and 90 days of life from 14.5 to $29 \%$. The calves of the two groups received $85 \mathrm{~kg}$ of reconstituted milk between 6 and 90 days of life. The two techniques recorded overlapping performances, and therefore it was shown that it is possible to reduce the use of labor. The calves reached the weight of $101.9 \pm 3.4 \mathrm{~kg}$ (group G1) against $104.3 \pm 3.7$ (group 
G2) at 90 days while those of Palladino et al. who received reconstituted milk between 10 and 60 days, at 80 days they weighed $93.2 \mathrm{~kg}$ (group $A$ which received $48.9 \mathrm{~kg}$ of reconstituted milk) and $84.9 \mathrm{~kg}$ (group B which received $40.7 \mathrm{~kg}$ of reconstituted milk). At 90 days, considering the daily weight gain recorded between 70 and 80 days, it is probable that they would have reached the weight of 96.9 and $89.7 \mathrm{~kg}$, despite having received $40 \mathrm{~kg}$ of reconstituted milk less than those reported by other authors [7].

The daily weight gain between 6 days and 90 days was on average $655 \mathrm{~g}(633+677) / 2$, in the Vecchio et al. trial [7] and $666 \mathrm{~g}(726+607) / 2$ between 10 days and 80 days in that of Palladino et al. [6]. The total daily dry matter is taken from the calves of the Vecchio et al. test. It was between $2 \%$ (group G1) and $1.7 \%$ (group G2) per $100 \mathrm{~kg}$ of live weight while in the test Palladino et al., the values ranged from $1.65 \%$ to $1.75 \%$. The total daily dry matter observed by Vecchio et al. [7] was, therefore, higher.

In the test Vecchio et al. $57.73-53.27 \%$ of the ingested dry matter was represented by reconstituted milk (MR) while this concerned Palladino et al. for 54.4 and $45.43 \% \mathrm{Kg} /$ day of which 0.633 and $0.677 \mathrm{gr}$ were represented by reconstituted milk. The total daily dry matter taken by the calves of the two tests and other data are shown in Table 2. It appears that the amount of RM affects the final live weight and, consequently, the increase in daily weight.

Previous studies $[8,9]$ showed that 300 -day buffalo calves have an average daily weight gain of approximately $800 \mathrm{~g} /$ day. The diet administered was characterized by $0.89 \mathrm{MFU} / \mathrm{kg}$ dry matter (DM), which did not allow these animals to compensate for growth.

A subsequent study was conducted on 240 male buffaloes, weaned at $80 \mathrm{~kg}$ when they were 90-100 days old. After weaning, the animals received an ad libitum diet characterized by $0.80-0.85 \mathrm{~kg}$ of MFU / DM with a concentrated / forage ratio of 50:50. In this experience from the beginning of the test, a diet characterized by $0.9 \mathrm{MFU} / \mathrm{kg}$ of dry matter (DM), $14 \%$ $\mathrm{CP}$ and with a forage/concentrate ratio of $38: 62$ starting from an average age of $148,218,302,320,374$ and $596)$ days for 1, 2, 3, 4, 5 and group 6 respectively.

The weight gain was recorded monthly up to the slaughter of about $400 \mathrm{~kg}$. Unfortunately, due to the needs of the market, buffaloes were slaughtered at different weights and ages. To this end, the performances obtained at $400 \mathrm{~kg}$ and 550 days were recorded and analyzed. It is worth noting that the age, weight, and growth of buffaloes slaughtered after 400 $\mathrm{kg}$ and 550 days were also recorded. The weight of subjects slaughtered after 550 days of age was obtained with appropriate interpolations between weight and age.

The buffaloes that received the diet at an average age of 148 days weighed $486 \mathrm{~kg}$ at 550 days. The age at which the diet was administered was inversely related $\left(R=-0.689^{* *}\right)$ to the weight of $400 \mathrm{~kg}$ (Table 3) and, consequently, directly related to the daily weight gain. The dry matter intake ( $\mathrm{kg} /$ day) was lower in the animals who received the diet at the age of 302 days (groups 1,2, and 3) than in those (groups 4, 5 , and 6) who received the diet later. These differences were present both when considering live weight (400 $\mathrm{kg}$ ) and when considering age (550 days).

Daily weight gain tended to increase between 350 and 400 days and 550 days in Groups 1 and 2 (Table $3)$. In the other groups, it always increased after the administration of the diet, with the exception of group 3 . It is interesting to note that in groups 3,4 , and 5 , the daily weight gain (DWG) decreased after a period during which it was greater than $1 \mathrm{~kg}$. Although the diet was administered ad libitum, a daily weight gain of 1.2$1.3 \mathrm{~kg}$ was only recorded in group 3 between 400 and 500 days. DM intake increased to $345 \mathrm{~kg}$, while it progressively decreased in relation to body weight (from $2.8 \%$ to $1.6 \%$ of live weight).

Table 3: Age (days) at which the subjects reached $400 \mathrm{~kg}$ of live weight and daily weight gain from the birth, in relation to the start of diet $\mathrm{A}(0.9 \mathrm{MFU} / \mathrm{kg} \mathrm{DM})$ administration (age)

\begin{tabular}{|c|c|c|c|c|c|c|}
\hline group & $\mathbf{1}$ & $\mathbf{2}$ & $\mathbf{3}$ & $\mathbf{4}$ & $\mathbf{5}$ & $\mathbf{6}$ \\
\hline \hline Average age (days) & 458 & 540 & 568 & 618 & 619 & 636 \\
\hline daily weight increase (kg) & 0.797 & 0.676 & 0.643 & 0.590 & 0.590 & 0.574 \\
\hline$*$ & $\mathrm{~A}$ & $\mathrm{~B}$ & $\mathrm{C}$ & $\mathrm{D}$ & $\mathrm{D}$ & $\mathrm{D}$ \\
\hline
\end{tabular}

*different capital letters between the columns express statistical significance for $P<0,01$ 
Table 4: Daily Weight Gain (kg) in a Different Range of Age

\begin{tabular}{|c|c|c|c|c|c|c|}
\hline group & 1 & 2 & 3 & 4 & 5 & 6 \\
\hline & \multicolumn{6}{|c|}{ Daily weight gain } \\
\hline Days of age & $\mathrm{kg}$ & $\mathrm{kg}$ & $\mathrm{kg}$ & $\mathrm{kg}$ & $\mathrm{kg}$ & $\mathrm{kg}$ \\
\hline 150 & 0.615 & 0.463 & 0.436 & 0.488 & 0.558 & 0.522 \\
\hline 250 & 0.775 & 0.575 & 0.436 & 0.488 & 0.558 & 0.522 \\
\hline 300 & 0.850 & 0.698 & 0.436 & 0.488 & 0.695 & 0.691 \\
\hline 350 & 1.121 & 0.800 & 0.456 & 0.863 & 0.596 & 0.200 \\
\hline 400 & 1.045 & 0.876 & 0.912 & 0.741 & 0.748 & 0.400 \\
\hline 450 & 0.769 & 0.876 & 1.316 & 1.240 & 0.841 & 0.600 \\
\hline 500 & 0.754 & 0.840 & 1.285 & 0.537 & 1.166 & 0.800 \\
\hline 550 & 1.078 & 0.840 & 0.615 & 0.257 & 0.194 & 0.300 \\
\hline 600 & 0.840 & 0.440 & 0.333 & 0.268 & 0.700 & \\
\hline 650 & 1.010 & 0.660 & 0.300 & 0.640 & 1.212 & \\
\hline 700 & 0.996 & 0.800 & 0.160 & & & \\
\hline 750 & 0.862 & 0.200 & & & & \\
\hline 800 & 0.410 & & & & & \\
\hline
\end{tabular}

Similar to what was observed in a previous study [8], late administration of the diet did not allow for a compensatory DWG, as usually demonstrated in cattle. This phenomenon may be due to the fact that DM intake is stable until animals reach a critical bodyweight, after which the DWG lowers. The results of this study have shown that in order to properly evaluate growth parameters in buffalo species it is necessary to take into account its growth from birth.

The daily weight gain tends to increase between 300 and 400 days in groups 1 and 2 after about 6.5 months from the administration of diet A characterized (Table 2) by a higher energy density (0.9 MFU / kg of dry matter - DM -, 14\% CP, and a forage/concentrate ratio of 38:62 against 0.80-0.85 MFU / $\mathrm{kg} / \mathrm{DM}$ and a forage/concentrate ratio of 50:50 both administered ad libitum). Improvement in daily weight gain was observed after 8-9 months in groups 3, 4, and 5 and after 11.5 months in group 6 . Eventually, the benefit was less with increasing the age at which diet $A$ started. The phenomenon can be explained if we consider that the percentage intake of DM / live weight progressively decreases from $2.8 \%$ to $1.6 \%$ with the increase in live weight (from 120 to $510 \mathrm{~kg}$ of live weight).

Similar results have been observed in a previous study (Zicarelli et al., 2005): the late administration of a better diet did not allow a compensatory DWG, as usually happens in cattle. This phenomenon may be due to the fact that DM intake is stable until animals reach a critical bodyweight, after which the DWG lowers. The results of this study reinforced the thesis that, in order correctly evaluate the growth parameters in buffaloes species, growth from birth must be considered.

\section{CONSUMPTION OF MILK REPLACER AND AGE AT FIRST CALVING}

The contributions reported so far (nor do we know that other researchers have studied it) have not taken into account the influence of weaning and, in particular, the quantity of reconstituted milk taken, on age at first calving. It seemed to me useful to report a field observation by processing the data of a company it owns five farms for a total of about 9000 heads.

The 10-year data were archived daily (personal communication), and it was possible to verify that after weaning, the calves receive the same type of rationing. The weaning period and the quantity of reconstituted milk administered, verified based on the invoiced amounts, for different reasons, however, differed between the five companies.

It was, therefore, possible to verify "ex-post" on 3672 buffaloes of first calving that those who had taken a more significant quantity $(150 \mathrm{~kg}$ vs. 105) of reconstituted milk had shown age at first calving (Figure 4) of about six months less (28, 5 against 34 ).

Ultimately, this advance was obtained with a surplus of $45 \mathrm{~kg}$ of reconstituted milk, therefore, with an increase in costs of approximately $€$ 90, which corresponds to a quantity of $60 \mathrm{~kg}$ of buffalo milk, 


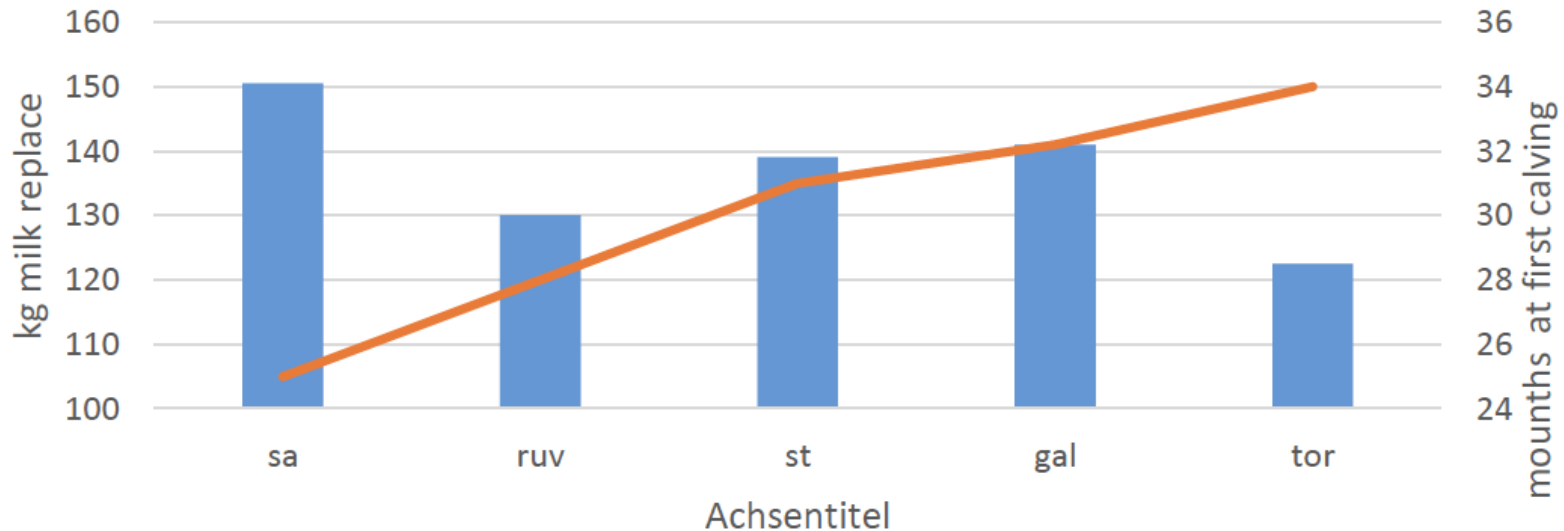

age at 1st calving $\quad$ kg milk replacer

Figure 4: Intake of milk replace $(\mathrm{kg})$ and age at $1^{\text {st }}$ calving $(r=0.955)$.

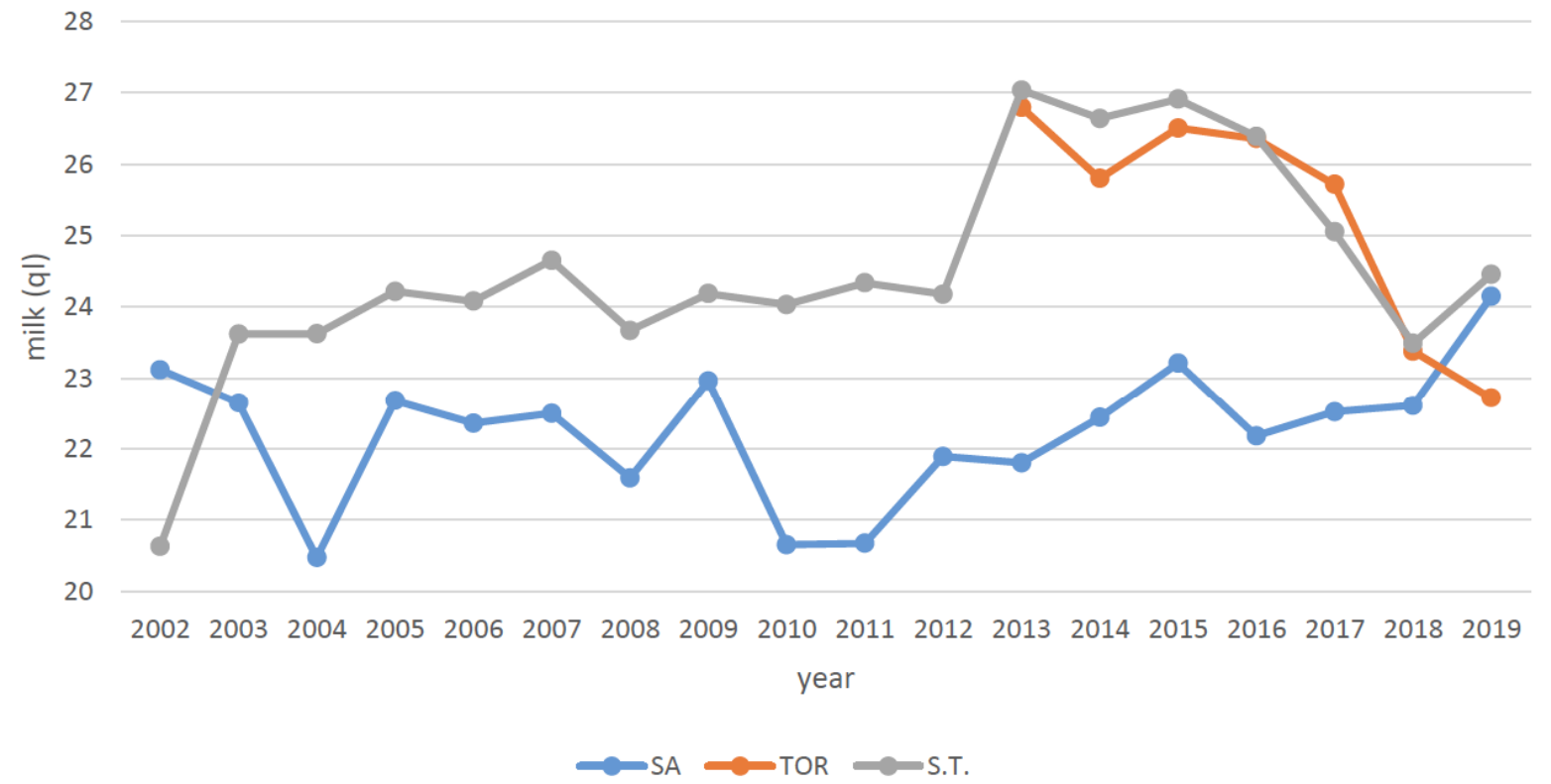

Figure 5: Advance to the first birth and production ( $q$ l = quintals) of milk observed in the primiparous of three herds: SA, TOR and ST 34, 32 and 25 months to the first birth respectively.

which for a career of 5 parts corresponds to $12 \mathrm{~kg}$ of milk/calving. This higher cost is easily compensated anticipating production by 6 months. However, it was observed that on farms where the first calving occurred six months in advance, the females of the first calving had produced $300 \mathrm{~kg}$ less than in previous years (Figure 5). This lower production had already been recovered at the second calving (Figure 5).

\section{CONCLUSION}

The breeding and weaning of buffalo calf present specific species peculiarities that influence not only the growth but the age at first calving and the future reproductive career.

\section{REFERENCES}

[1] Roldan Calle CP. Buffalo Breeding in Colombia, Atti $3^{\circ}$ Congresso Nazionale sull'Allevamento del Bufalo, !st Buffalo Symposium of Europe and the Americas, 12 - 15 Oct. 2005, Capaccio - Paestum (SA) - Italy, 2005; 34-40.

[2] Zicarelli L, Macri' A, Vittoria A, Padula P, Costantini S, Rania V, Giordano R. Intossicazione da rame in vitelli bufalini. Rivista di Zootecnia e Veterinaria 1981; 9(4):: 246-251.

[3] Ferrara B, de Franciscis G, Minieri L, Intieri F. Prove di alimentazione di vitelli bufalini con latte di bufala e con latte di vacca. Atti Soc It Sci Vet 1964; 21: 446-448.

[4] Zicarelli L. Consideration about the prophylaxis of the uterine and vaginal prolapse in Italian Mediterranean buffalo cows. Bubalus Bubalis, III, 2000; 71-90.

[5] Ferrara B, e Intieri F. Caratteristiche e impiego de latte di bufala Rivista di Zootecnia e Veterinaria 1976. 
[6] Palladino M, Di Meo C, Esposito L, Zicarelli L. Prove di svezzamento in vitelle bufaline con l'impiego di un latte ricostituito acidificato. In: Proceeding 10th National Congress. ASPA, Bologna 1993; 261-266.

[7] Zicarelli L. Buffalo calf weaning and production. In: Proceeding 3rd Simposio Bufalos de las Americas-2nd Simposio de bufalos de bufalos Europa-America, Medellin, Columbia 2006; 80-86.

[8] Zicarelli L, Gasparrini B, Amante L, Campanile G, Di Palo R. Mediterranean italian buffalo young bull production. Note I: relationship among grooving parameters. Atti $3^{\circ}$ Congresso Nazionale sull'Allevamento del Bufalo, 1st Buffalo Symposium of Europe and the Americas, 12 - 15 Oct. 2005, Capaccio - Paestum (SA) - Italy 2005; 128-129.

[9] Zicarelli L, Ariota B, Gasparrini B, Neglia G, Di Palo R. Buffalo Beef Production. Italian Journal of Animal Science 2007; 6(sup2): 1313-1315.

https://doi.org/10.4081/ijas.2007.s2.1312

Received on 27-03-2020

Accepted on 18-05-2020

Published on 05-06-2020

DOI: https://doi.org/10.6000/1927-520X.2020.09.11

(c) 2020 Luigi Zicarelli; Licensee Lifescience Global.

This is an open access article licensed under the terms of the Creative Commons Attribution Non-Commercial License (http://creativecommons.org/licenses/by-nc/3.0/) which permits unrestricted, non-commercial use, distribution and reproduction in any medium, provided the work is properly cited. 